This item is the archived peer-reviewed author-version of:

\title{
Willingness to pay for watershed conservation: are we applying the right paradigm?
}

\section{Reference:}

Lalika Makarius, Meire Patrick, Ngaga Yonika M., Sanga Goddy J..- Willingness to pay for watershed conservation: are we applying the right paradigm?

Ecohydrology and hydrobiology - ISSN 1642-3593 - 17:1(2017), p. 33-45

Full text (Publisher's DOI): http://dx.doi.org/doi:10.1016/J.ECOHYD.2016.12.004

To cite this reference: http://hdl.handle.net/10067/1444270151162165141 


\title{
Willingness to Pay for Watershed Conservation: Are we applying the right paradigm?
}

\section{Makarius C.S. Lalika ${ }^{a b 1}$, Patrick Meirea , Yonika M. Ngagac ${ }^{c}$ and Goddy J. Sanga}

aDepartment of Biology, Ecosystem Management Research Group, University of Antwerp, Campus Drie Eiken,Universiteitsplein 1 BE-2610 Antwerp, Belgium.

${ }^{b}$ Department of Geography and Environmental Studies, Solomon Mahlangu College of Science and Education, Sokoine University of Agriculture, P.O.Box 3038 Chuo Kikuu, Morogoro, Tanzania.

'Department of Forest and Environmental Economics, College of Forestry, Wildlife and Tourism, Sokoine University of Agriculture, P.O.Box 3011 Chuo Kikuu, Morogoro, Tanzania.

dDepartment of Agriculture Economics and Agribusiness, College of Agriculture, Sokoine University of Agriculture, P.O.Box 3007 Chuo Kikuu, Morogoro Tanzania.

\begin{abstract}
The values of watershed services from watersheds has for many years been neglected, underestimated and not factored in land use decisions for sustainable management. Sustainable management of watersheds and environmental friendly economic activities are vital for sustained water flow, steady supply of ecosystem services for societal needs and enhancement of aquatic vegetation and animal species. The problem of the failure to capture actual values of ecosystem services from watersheds and incorporate them in the national income accounting is profound in developing countries which are characterized with constrained budget for financing conservation programs. To resolve this problem attention has moved to market based instruments such as payment for watershed services (PWS). However, the approach to elicit the necessary information for PWS to kick off is still lacking. Furthermore, the application of market-based

\footnotetext{
${ }^{1}$ Corresponding author:

Department of Geography and Environmental Studies, Solomon Mahlangu College of Science and Education, Sokoine University of Agriculture, P.O.Box 3038 Morogoro Tanzania. Cell phone: +255 754 201306; Fax: +255 23 2604648; 25523 2603404; E-mail address : makarius.lalika@yahoo.com; lalika_2mc@suanet.ac.tz
} 
approaches in watershed conservation is vital as it advocates ecohydrology discipline, i.e. the integrative science linking the interaction between hydrology, biota and natural processes as management tools to reinforce ecosystem services on a broad range of landscapes. This study investigated small holder farmers' willingness to pay (WTP) for watershed services in Pangani River Basin. A contingent valuation method was employed to elicit the willingness to pay for watershed conservation. A probit model was used to determine respondents' response to WTP and factors conditioning the maximum amount they are WTP. Findings indicates that majority of respondents are willing to pay for watershed services. Similarly, result reveals that marital status, household size and distance from the water source positively influence smallholder farmers' WTP and the maximum amount to be paid. Equally important occupation, household size, income from irrigation, and amount paid for irrigation were found to negatively influencing smallholder farmers' WTP. The result also revealed that education level, total land size and yield from irrigated farm plot positively influence smallholder farmers' WTP. These results therefore, indicate that establishment of PWS is feasible.

Key words: Contingent valuation, Ecosystem services, Watershed ecosystem, Tanzania

\section{INTRODUCTION}

\subsection{Watershed conservation and ecosystem services supply}

For decades watershed ecosystems have been taken for granted and the ecosystem services (ES) from therein have been regarded as free resources (Tietenberg, 2002) and sometimes considered as common (pool) property resources (Mbeyale, 2009; Ostrom et al., 1993; Ostrom, 1990). Watershed ecosystems are potential for the provision of ES ranging from provisioning, regulating, supporting to cultural services (Costanza et al., 1997; De Groot et al., 2002; MEA, 2005; Lalika et al., 2014). However, their socioeconomic and ecological significance have subjected them to severe threats in such a 
way their potential to release watershed services has been dwindling (Tietenburg, 2002; Liquete et al., 2011). Analysis from the Millennium Ecosystem Assessment indicated that $60 \%$ of ES are under unsustainable use (MEA, 2005). Drivers for the degradation of watershed ecosystems include anthropogenic activities (such as unsustainable agriculture, excessive harvesting of forest products, mining activities, and overgrazing) and natural drivers such as climate change and variability. This degradation has altered their long-term capacity to provide provisioning, regulating, supporting and cultural ecosystem services at levels that can sustain welfare of the current and future generations (Calder, 2007; Stanton et al., 2010; Liquete et al., 2011).

The Pangani River Basin (PRB) presents a compelling case for analysis of the feasibility of payment for watershed services (Kulindwa, 2005; Lalika et al., 2011). Kilimanjaro and Meru Mountains are regarded as the water towers because they are the catchment where Pangani River originates (IUCN and PBWO, 2008). The two catchments play an important role in providing fresh water to communities downstream. Their capacity to reduce run-off, percolate and slowly release water downstream has made the basin to become productive throughout the year. The watershed provide water for large and small scale irrigation, domestic and industrial use, hydropower production (at Nyumba ya Mungu Dam); for ecological processes along Pangani River and for nutrient cycling at Kirua Swamp (Mwamila et al., 2008). Nevertheless, the increase of population along the PRB (Mbonile, 2005) triggered the change of prior land uses to new ones in search for ES to support the growing population. Rampant population influx in PRB accelerated urbanization which called for more area for human settlement, agriculture and supply of water for the increased domestic and industrial uses. Consequently, the change of land use in search for watershed services has accelerated degradation of the watershed, hence reduction of water flow along the PRB (Lalika et al., 2015a; b). 
To reverse the harm done on the watershed an integrated conservation approach which brings together upstream communities and downstream water users is deemed important to complement the traditional command and control policy instruments (MEA, 2005; Pagiola, 2004a; 2008; Porras et al., 2008). Marked-based approaches for conservation have been tipped as ideal policy tools for watershed conservation (Pagiola et al., 2004b; Locatelli and Vignola, 2009; Okurut, 2011; Khanal and Paudel, 2012). The economic logic behind this argument is that the later instruments acting on their own have not been sufficient to address the problems facing the management of watersheds (Dobbs and Pretty, 2008). In particular, command and control instruments have not exploited the potential of upstream land holders and downstream ecosystem services beneficiaries in achieving conservation goals. Market based instruments provide incentives to upstream land holders to manage the catchment in manner that ensure continued supply services to downstream users (Pagiola et al., 2004b; Pagiola et al., 2005; Turpie et al., 2008). Equally important, market based instruments are considered important as they will motivate upstream land holders to take into account the effects of their actions when making decisions about their own land use (Okurut, 2011).

However, some key empirical analysis of downstream users who are willingness to pay (WTP) for the services provided to upstream land holders is crucial before establishing the downstream-upstream market link (Whittington, 2002; Locatelli and Vignola, 2009; Mohamed et al., 2012; Calderon et al., 2005). The actual values of watershed services has for many years been neglected, underestimated, not captured in the national income accounting and not factored in land use decisions for sustainable management along PRB (Lalika et al., 2011). Thus undertaking a study on WTP for watershed conservation is crucial.

\subsection{Willingnes to pay (WTP) and valuation of ecosystem services (ES)}

Watershed ecosystems provide innumerable ecosystem goods and services to the society (Locatelli and Vignola, 2009). Human beings depend of ES from different 
ecosystems and sustainable flow of ES depends much on well-functioning ecosystems. For quite some time, ecological economists have been researching in order to better understanding how these ES are valuable to human being and in the production process (Pattanayak and Kramer, 2001; Costanza et al., 1997, Heal et al., 2005). Unfortunately, the economic value to society of these ES are frequently undervalued and sometimes not captured along the PRB because of lack knowledge regarding the role that watershed ecosystems play in offering ES or because these ES are indirect and therefore, difficult to quantify. Thus researches to ensure that watershed ecosystems along the PRB are carefully conserved to ensure sustainable supply of ES and that these ES are properly documented and quantified are crucial (Lalika et al., 2015c). More importantly, it is high time to carry out empirical studies so as to document the people's WTP for watershed conservation.

Across the globe, ecological economists have been using individual preference based approaches for estimating the demand for ES in order to cope with challenges of values / prices of ES in the absence of market prices (Champ et al., 2003). Contingent Valuation Method (CVM) is among the most preferred approaches for achieving this purpose. CVM is advocated by majority because it presents individuals with a theoretical market for a change in quality or quantity of ES by asking them to state and /or rank their WTP. Therefore, their preferences of a certain ES is determined or indicated by the amount of money assigned by their WTP (Voltaire et al., 2013).

There are a number of economic theories and school of thoughts about individual preferences on WTP. For instance, the microeconomic theory of consumer behavior assumes that any choice by individuals have a well-defined preference for that particular choice (Pindyck and Rubinfeld, 2005). For valuation purposes of ES, individuals are capable of indicating their preferences (in financial terms) by stating an exact WTP for any change in the provision of ES. According to Bateman et al. (2005), 
and Hanley et al. (2009), at some instance some individuals fail or feel uncertain to asign a value to a specific ES during valuation studies.

Understanding of the values that people place ES is critical to making sound management and economic decisions (Lalika et al., 2015c). In many cases, markets provide an easy way for people to reveal value through their decisions to buy and sell ES. But in other cases, markets fail to accurately reflect actual values. Whether it's because the ES being valued does not have a market, or existing markets fail to reflect the full value of the ES, non-market valuation methods are needed to fully measure the costs and benefits of ES (Haab and McConnell, 2003; Awad and Holländer, 2010). Therefore, this doctoral study (based on the CVM) was carried out to elicit people's WTP in order to gather information for designing and establishment of PWS scheme along the PRB, Tanzania. CVM was preferred in this doctoral study because it is widely applied to the problem of estimating economic values of ES that are not traded in markets and for which no economic behavior is observable (Pattanayak and Kramer, 2001; Heal et al., 2015). Furthermore, CVM was applied in this research because these non-markets characteristics are normally present when the ES in question is in the form of an environmental amenity.

Therefore, CVM was preferred and applied in this study so as to elicit the willingness of a household to pay for water flow that will produce benefits for that particular household. CVM has the ability estimate the total WTP based on people's direct statements of their preferences. Specifically the study (i) Identified respondent's socioeconomics characteristics and their perceptions on the market based arrangement for watershed conservation; (ii) Identified socio-economic drivers and marginal effects for WTP for watershed conservation; (iii) Determined the factors influencing the maximum amount for WTP for conservation. 


\section{MATERIALS AND METHODS}

\subsection{Description of the study area}

\subsubsection{Location}

This study was conducted in eight villages; four (Kaloleni, Chekereni, Rau River and Mabogini) in Kilimanjaro Region and the other four (Lekitatu, Karangai, Msitu wa Mbogo and Kikuletwa) in Arusha Region the Pangani River Basin (Figure 1).

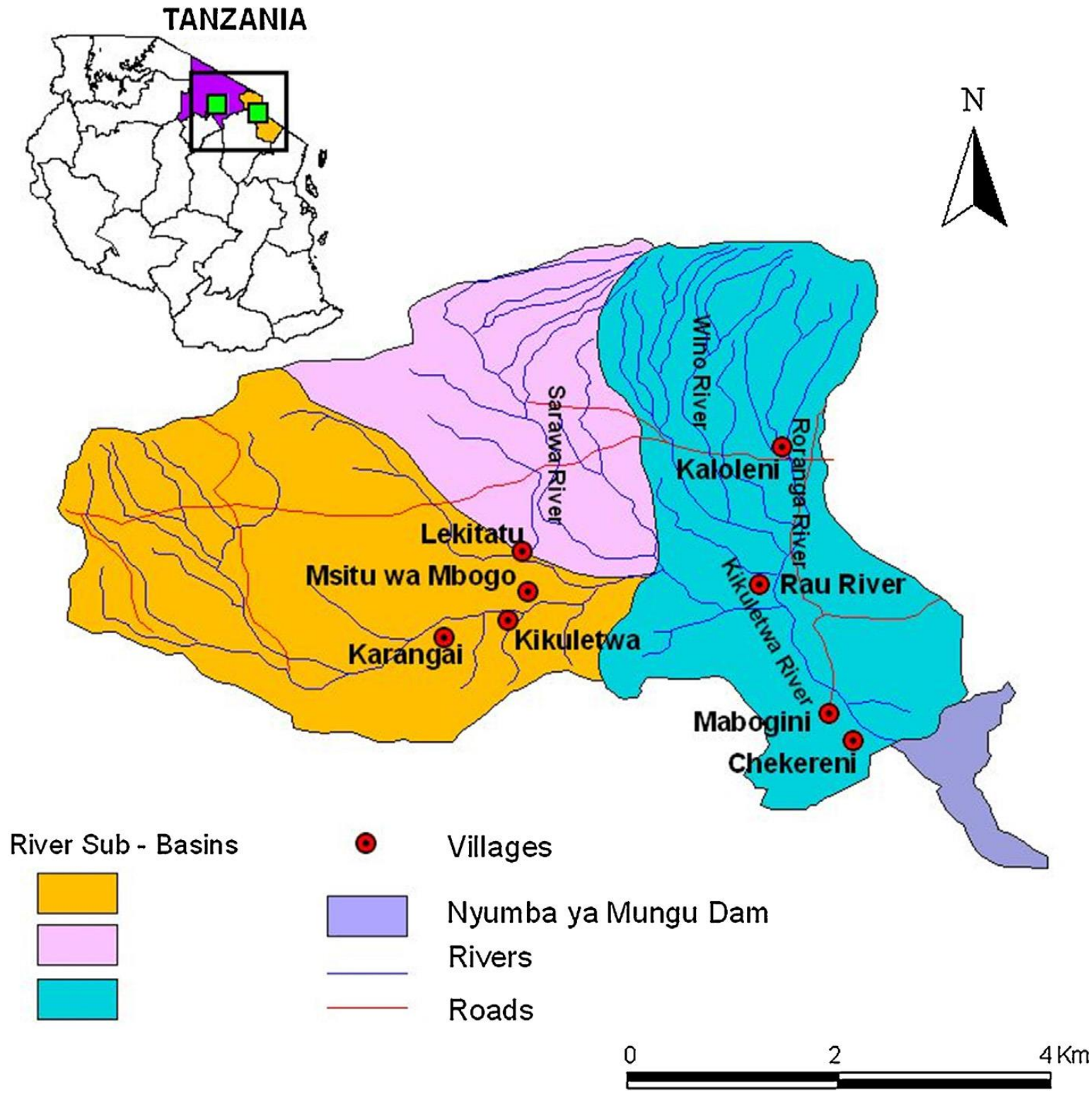

Figure 1: Location of the study area along Pangani River Basin, Tanzania 
The PRB is located at latitude $03^{\circ} 05^{\prime} 00^{\prime \prime}$ and $06^{\circ} 06^{\prime} 00^{\prime \prime}$ South and longitude $36^{\circ} 45^{\prime} 36^{\prime \prime}$ and $39^{\circ} 36^{\prime} 00^{\prime \prime}$ East. It drains a large catchment in the northeastern part of the country along the border with Kenya, extending from Mount Meru and Kilimanjaro down through the Pare and Usambara Mountain ranges (IUCN and PBWO, 2008).

The basin has a total catchment area of about $43,650 \mathrm{~km}^{2}$ with about 3,914 $\mathrm{km}^{2}$ lying in Kenya (IUCN, 2007). Pangani River Basin is unique in the fact that it begins from the highest pick of mountain in Africa, Mount Kilimanjaro (which is 5,895 m asl) and Mount Meru (which is 4,565 m asl) through the Pare and Usambara Mountains to the north and north-east respectively to the low lands of about $900 \mathrm{~m}$ asl and $0 \mathrm{~m}$ asl. The low lands make up about $50 \%$ of the basin (Valimba, 2005).

\subsubsection{Hydrology and drainage pattern}

The hydrology and drainage pattern in the PRB catchment varies considerably. The PRB comprises of several sub-catchments of widely different characteristics. The Pangani River (PR), which is also referred as the Pangani Mainstream, rises as a series of several small streams and springs on the southern sides of the Africa's highest peak Mt. Kilimanjaro, and on Mt. Meru (IUCN and PBWO, 2008; IUCN, 2007). These streams (Nduruma, Tengeru, Sanya, Malala, etc.) create the Kikuletwa and Ruvu Rivers (Himo, Muraini, etc.) which drain further downstream into the Nyumba ya Mungu (NyM) dam (IUCN and PBWO, 2008; 2011; IUCN, 2007). The Nyumba ya Mungu dam has created a

man-made water reservoir of ecological and economic importance along PRB. The overflow of the dam (outlet) is known as the Pangani River Mainstream and flows for $432 \mathrm{~km}$ before emptying into the Indian Ocean at the Pangani estuary.

The Nyumba ya Mungu reservoir is the largest water body in the PRB and was constructed in 1965 to enhance river flows for hydropower generation. It was later incorporated into irrigation plans (Mulungu, 1997; Ndomba et al., 2008). Besides the 
power station at the outlet of this dam, other hydropower power plants in the PRB are located near Hale and New Pangani Falls. Water released from the Nyumba ya Mungu dam supply ecosystem services downstream. These include nutrient cycling at Kirua Swamp and enhancement of ecological processes (e.g. hindering salt water intrusion and coastal erosion) at the estuary mouth in Pangani Town (Ndomba et al., 2008; Shaghude, 2006; Sotthewes, 2008; Valimba, 2005; 2007). Other river tributaries draining in the PRB are Mkomazi and Luengera from the Pare and Usambara Mountains ranges respectively.

\subsubsection{Forest and vegetation types}

Forest and vegetation in PRB range from forests on mountain slopes to semiarid grasslands (IUCN, 2003). The main vegetation types include forests, woodlands, bush land, along with grassland thicket and plantation forest (Turpie et al., 2005). Plantation forests have replaced natural forests in the highlands, and the larger part of the lowlands is composed of woodland, bush land, grassland and thicket. Forests perform vital hydrological functions in the PRB including the regulation of run-off, prevention of soil erosion, water storage and improvement of water quality (IUCN, 2003; Msuya, 2010). According to IUCN (2003), dominant forest types in PRB include: mangrove forests (located at the confluence of the Pangani River and the Indian Ocean and protecting the coastlines and soft sediment shorelines from erosion, trapping sediments and recycling nutrients); East African coastal forests (containing remarkable levels of biodiversity and endemism); afromontane forests (playing a key part in hydrological functions); and riverine forests (controlling erosion along the river banks). Research and previous studies on forest health conducted in the PRB shows that between 1952 and 1982, catchment forests in the PRB declined at a fairly high rate of $3.8 \%$ of forest cover per year, whilst farmlands and settlements increased dramatically by $83 \%$ of forest cover per year (Lambrechts et al., 2002; Newmark, 1998). 


\subsubsection{Climate}

Variations in the local climate in the PRB are mostly related to topography. The flatter, lower-lying south-western half of the Basin is arid and hot, while the mountain ranges along the northern and south-eastern catchment boundaries have cooler, wetter conditions. The high altitude slopes above the forest line on Mt Meru and Mt Kilimanjaro have an Afro-Alpine climate and receive more than 2,500 $\mathrm{mm}$ of rainfall per year. Mean annual rainfall increases in a southerly direction along the mountain ranges, and varies from about $650 \mathrm{~mm}$ per year in the North and South Pare Mountains, to 800 mm per year in the Western Usambara Mountains, and 2,000 mm per year in the Eastern Usambara Mountains.

\subsubsection{Population and economic activities}

The PRB is estimated to have 4.5 million people (data from 2007) and population densities vary between highlands and lowlands. About $90 \%$ of the basin's population resides in the highlands with some 900 people per $\mathrm{km}^{2}$, while lowland densities were around 65 people per $\mathrm{km}^{2}$ (IUCN, 2003). The main causes of forest degradation and deforestation include encroachment for settlement and agriculture as well as increasing demand of forest products (mainly timber and fuel wood) (IUCN, 2003). In terms of human population, PRB is a densely populated area in Tanzania, posing serious challenges to sustainable watershed management (Msuya, 2010).

\subsection{Sampling procedure}

Field visits were first carried out along the PRB for village identification and sampling purposes. A simple random sampling technique was used to select the sampling units (i.e. households) in order to avoid bias. We used this sampling technique in order to give each household in each village and every member of the household (aged 18 years and above) an equal chance of being selected. The sampling frames for this study were the village register books containing the list of all households in the respective villages. We sampled 8 villages, 4 in Arusha Region and 4 in Kilimanjaro Region and in each 
village we sampled $10 \%$ of the total households as indicated in Table I.

Table I: Interviewed respondents in the study villages

\begin{tabular}{lcrrr}
\hline Region & District & Village & $\begin{array}{r}\text { Total } \\
\text { households }\end{array}$ & Respondents \\
& & Lekitatu & 250 & 25 \\
Arusha & \multirow{3}{*}{ Meru } & Karangai & 480 & 48 \\
& & Kikuletwa & 640 & 64 \\
& & Msitu wa Mbogo & 420 & 42 \\
\cline { 3 - 5 } Kilimanjaro & Moshi Urban & Kaloleni & 490 & 49 \\
& & Chekereni & 550 & 55 \\
& \multirow{2}{*}{ Moshi Rural } & Rau River & 340 & 34 \\
& & Mabogini & 430 & 43 \\
\hline Total & & & 3600 & 360 \\
\hline
\end{tabular}

In each village, we randomly selected respondents using a table of random numbers. The respondents were selected by matching their numbers in the village register books. We used both quantitative and qualitative methods in data collection.

\subsection{Questionnaire design and bid amounts}

The household questionnaires for this survey were constructed and designed with the purpose of capturing all necessary information to answer research questions of this research. Key sections includes: socio-economic characteristics of the household/respondents; household income and sources; different water uses; and villager's perceptions towards changes in watershed services.

The questionnaire had the following sections: i) The valuation scenario (i.e. where we introduced the respondents the mission of our survey, types ES delivered by watersheds, why they should be conserved and paid for, etc.); ii) The status of watersheds (i.e. they are degrading and that continued degradation will result in significant reduction of ES and if they think conservation would restore the situation); iii) Initiatives set by the government and donor agencies on watershed conservation (i.e. if they are willing to contribute for increased unit of water flow; bids and payment 
methods); iv) If they are willing or unwilling to pay and why?; v) Certainty of their willingness and unwillingness to pay; vi) Their willingness to wait for longer periods in order ES to flow as a result of their payments and their opinions if they think PWS would enhance watershed conservation).

Including the above questions in the questionnaire was important for capturing different information related to socio-economic status and WTP for watershed conservation. This methodological approach conforms to research carried out by Loomis et al. (2000), Zhongmin et al. (2003), and Herrera et al. (2004), who contended that a clear explanation of $\mathrm{CV}$ variables to be studied is crucial in valuation studies because it gives a better understanding of the variables that affect the household's WTP, which is an important key to identify the hypothetical situation; it help to elicit the range of amount / values of WTP through binary (close ended) choice questions; and by ensuring accurate benefit estimates of the ecosystem good and services under study.

In this regard, we set questions in the form of binary/dichotomous, i.e. respondents had two options $(1=$ yes and $0=\mathrm{No})$. We designed bids amount in a form of payment cards assigned values (ranging from Tanzanian shillings 0 - 75,000 where respondents were required to mention or circle the amount they were willing to pay? These bids were finally set after a careful pre-testing and feedback from smallholder farmers along the PRB.

Before actual interviews (data collection), we trained research assistants on the appropriate way to administer CV questions. We introduced them about the meaning of ecosystem services, willingness to pay for ecosystem services, watershed degradation, standard description on the CV scenario, to name just a few. Furthermore, we trained research assistants on several issues related to the $\mathrm{CV}$ questionnaire including opinion questions aimed at reminding respondents the benefits and constraints of watershed degradation. In the CV questionnaire, we selected payment 
vehicle as the water use fees. Respondents were also asked if they would be WTP for monthly or annual fee for watershed conservation. Based on the respondent's previous answer, research assistants were also trained on how to ask follow-up questions for lower or upper amounts of water use fees.

\subsection{Data collection}

For quantitative data, we used structured questionnaires (with the CV scenario) as the main tool for collecting primary (quantitative) data. The structured questionnaire covered questions on water uses, types of water sources, payment methods for water utilization, types of socio-economic activities; other goods and ecosystem services delivered by the PRB; and questions on WTP. As indicated in Table I, a total of 360 respondents were interviewed in eight villages, i.e. four (4) villages in Arusha and Kilimanjaro Region respectively.

We divided the study in two phases. During the first phase we carried out a field excursion with the aim of familiarizing ourselves with the study area and selecting study villages. We also pre-tested questionnaires in order to assess questions for their validity and reliability in the sampled villages.

In phase two, we carried out the actual survey (i.e. we administered structured questionnaires) where a total of 360 respondents were interviewed (Table I). We also collected qualitative data through informal and formal discussions and interviews. These discussions and interviews enabled us to enrich quantitative data collected through structured questionnaires. Furthermore, we also carried out group focus discussions (GFD) to supplement information collected through other methods. 


\subsection{Data analysis}

\subsubsection{Quantitative and qualitative data}

We coded and cleaned the 360 questionnaires for final analysis. We used Statistical Package for Social Sciences (SPSS) version 20.0 to analyze data. There after we carried out analysis to obtain frequency and percentages of responses from smallholder farmers who were willing or not willing to pay for watershed services. On the other hand, we analyzed qualitative data with the help of participants during group focus discussions through dialogue and intensive debates.

\subsubsection{The empirical model}

The study employed the CVM which is a hypothetical value based method used to estimate smallholder farmers' WTP for ecosystem services obtained from a watershed for sustainable management of the ecosystem. The approach was selected for this study because of its ability to assign a market value to ecosystem services which have no market values or cannot be assessed by market mechanisms (Bateman et al., 2002; Amponin et al., 2007).

To achieve the objective of the study, we therefore, employed un-observed latent variable as an underlying propensity to WTP. To get consistent results, the survey data were analyzed using probit model as suggested by Green et al. (1995), to examine more rigorously whether or not small holder farmers in Pangani Basin are different between the two lines of choices.

The model used takes the following form:

$$
y_{i}=\left\{\begin{array}{l}
1 \text { if } y_{i}^{*}>\tau \\
0 \text { if } y_{i}^{*} \leq \tau
\end{array}\right.
$$

Where: $\tau$ is the threshold of being different between the two lines of choices, and $y^{*}$ is the latent variable. 
As revived by Green (2003) the latent variable $\left(y_{i}^{*}\right)$ is assumed to be linearly related with observed variables $\left(x^{\prime} s\right)$ in the structural model and is presented as:

$$
y_{i}^{*}=x_{i} \beta+\varepsilon_{i}
$$

Where; $x$ is a vector of variables is hypothesized to influence WTP; $\beta$ is a vector of parameters estimated; and $\varepsilon_{i}$ is the random error assumed to be normally distributed with zero mean and unit variance (i.e. $\varepsilon \cong N(0, \sigma=1)$.

The probability of observing a small holder farmers saying 'YES' (i.e. $y=1$ ) is expressed as suggested by Long (1997)

$$
\operatorname{Pr}\left(y_{i}=1 \mid x_{i}\right)=\operatorname{Pr}\left(y_{i}^{*}>0 \mid x_{i}\right) \Rightarrow \operatorname{Pr}\left(y_{i}=1 \mid x_{i}\right)=\operatorname{Pr}\left(x_{i} \beta+\varepsilon_{i}>0 \mid x_{i}\right)
$$

As mentioned in above, the probability of an individual to be willing to pay for watershed services was estimated by using logit model such that;

$$
\operatorname{Pr}(y=1)=\frac{\exp \left(x_{i} \beta\right)}{1+\exp \left(x_{i} \beta\right)}=\frac{1}{1+\exp \left(x_{i} \beta\right)}
$$

The parameter estimated were interpreted as marginal effects, which indicates the effects of a marginal change of the variables conditioning willingness to pay for watershed services on the probability of saying 'yes'. Therefore, the marginal effects were estimated as follows;

$$
\frac{\partial \operatorname{Pr}(y=1 \mid X)}{\partial X_{i}}=\phi\left(x_{i} \beta\right) \beta_{i}
$$


Where: $\mathrm{Y}=$ is WTP taking values 0 and $1, \mathrm{X}=$ is a vector of factors that condition individual WTP, and $\beta=$ is a vector of variables estimated (Griffiths et al., 1993; Wooldridge, 2003; Sanga et al., 2013).

Note: that $Y$ is censored at zero for the sub-sample of small holder farmers that gave valid responses. Thus, to get consistent and robust results, the two-limit probit model as suggested by Rosett and Nelson (1975) was used to allow both upper and lower censoring to be captured in estimating the likelihood function for the model (see equation 6 and 7 respectively).

$$
y= \begin{cases}\tau_{L} & \text { if } y^{*} \leq \tau_{L} \\ y^{*}=x \beta+\varepsilon_{i} & \text { if } \tau_{L}<y^{*}<\tau_{U} \\ \tau_{U} & \text { if } y^{*} \geq \tau_{U}\end{cases}
$$

The likelihood function was estimated as follows:

$$
\ln L=\sum_{\text {Lower }} \ln \Phi\left(\frac{\tau_{L}-x \beta}{\sigma}\right)+\sum_{\text {Uncensored }} \ln \frac{1}{\sigma} \phi\left(\frac{y-x \beta}{\sigma}\right)+\sum_{\text {Upper }} \ln \Phi\left(\frac{x \beta-\tau_{U}}{\sigma}\right) .
$$

\subsubsection{Description of variable and model specification}

As explained in section 2.3 above responses on WTP was denoted by binary answers (dummy variables) where the response of respondents was "yes" denoted by the 0 value and "no" for 1 . Respondent's WTP for watershed conservation were hypothesized to be conditioned by a number of socio-economic drivers. They include: water use fee; gender; marital status; education level; occupation; household size; number household members engaged in income generating activities; total annual income; irrigation income; household water sources; distance from the water sources; amount of water from other sources; water for different uses (e.g. cooking, drinking washing clothes, dishes, toilets, bathing, etc.); price for water; total land size; amount paid for irrigation; quantity of crop yield with and without irrigation; and water use for irrigation. 
It was hypothesized that variables denoted by positive (+) and negative signs (-) (Table II) could influence positively and negatively people's WTP respectively. Moreover, some variables were assigned dummy (binary) values i.e. 0 for "yes" and 1 for "no".

Table II: Hypothesized direction opinion of socio-economic variables on WTP

\begin{tabular}{|c|c|c|c|}
\hline $\begin{array}{l}\text { Independent } \\
\text { Variable }\end{array}$ & Description & Measurements & $\begin{array}{l}\text { Hypothesized } \\
\text { direction of } \\
\text { opinion }\end{array}$ \\
\hline H2OUSEFE & Water use fee & Tanzania shillings & - \\
\hline GENDER & Gender & Male (0) or Female (1) & + \\
\hline MARITALS & Marital status & $\begin{array}{l}\text { Married(0) or otherwise } \\
\text { (1) }\end{array}$ & + \\
\hline EDUCAT & Education level & $\begin{array}{l}\text { Number of years spend } \\
\text { in education }\end{array}$ & + \\
\hline OCCUPAT & Occupation & $\begin{array}{l}\text { Employed (0) or not } \\
\text { employed(1) }\end{array}$ & + \\
\hline HHSIZE & Household size & $\begin{array}{l}\text { Total number of those } \\
\text { who generate income }(0) \\
\text { and those who doesn't } \\
\text { (1) }\end{array}$ & + \\
\hline PROPTHHE & $\begin{array}{l}\text { Number hh members engaged } \\
\text { in income generating activities }\end{array}$ & $\begin{array}{l}\text { Family members above } \\
15 \text { years old }\end{array}$ & + \\
\hline TOTANNUA & Total annual income & Tanzania shillings & + \\
\hline IRRIINCO & Irrigation income & Tanzania shillings & + \\
\hline NHHSOURC & Household water sources & $\begin{array}{l}\text { Tap water }(0) \text { or other } \\
\text { sources }(1)\end{array}$ & - \\
\hline DISTASOU & $\begin{array}{l}\text { Distance from the water } \\
\text { sources }\end{array}$ & In kilometres & + \\
\hline AMOH2OSO & $\begin{array}{l}\text { Amount of water from other } \\
\text { sources }\end{array}$ & $\begin{array}{l}\text { Number of buckets of } 20 \\
\text { litres }\end{array}$ & - \\
\hline $\mathrm{AMOH} 2 \mathrm{OCO}$ & Water used for cooking & $\begin{array}{l}\text { Number of buckets of } 20 \\
\text { litres }\end{array}$ & + \\
\hline AMOH2ODR & Water used for drinking & $\begin{array}{l}\text { Number of buckets of } 20 \\
\text { litres }\end{array}$ & + \\
\hline H2OUSWAS & $\begin{array}{l}\text { Water used for washing } \\
\text { clothes }\end{array}$ & $\begin{array}{l}\text { Number of buckets of } 20 \\
\text { litres }\end{array}$ & + \\
\hline H2OUSEDW & $\begin{array}{l}\text { Water used for washing } \\
\text { dishes }\end{array}$ & $\begin{array}{l}\text { Number of buckets of } 20 \\
\text { litres }\end{array}$ & - \\
\hline H2OUSEDT & Water used for toilets & Number of buckets of 20 & - \\
\hline
\end{tabular}




\begin{tabular}{llll}
\hline & & litres & \\
PRICEH2O & Price for water & Tanzania shillings & - \\
SIZELAND & Total land size (ha) & Number of hectares & + \\
AMOPAIDI & Amount paid for irrigation & Tanzania shillings & + \\
YIELDIRR & Yield with irrigation & In Kilograms & + \\
YIELDNON & Yield without irrigation & In Kilograms & - \\
H2OUSERI & Water use for irrigation & In litres & - \\
\hline
\end{tabular}

For instance, for gender, males were assigned a 0 value and 1 for females; for marital status, married respondents were denoted by 0 value and 1 for not married with; for occupation, employed respondents were given a 0 value and 1 for those not employ; for household composition, adults were assigned a 0 value and 1 for children; for household water sources, tap water was given a 0 value where as other water sources were denoted by 1 value (Table II).

The negative sign of the direction for water use fee was hypothesized that increase of water use fee was expected to reduce people's WTP. This is supported by economic theories that price influences the demand for good. Thus as the amount water use fee goes up it means demand for water decreases, and then the WTP for watershed conservation decreases. Education level was expected to increase WTP because many years of education improves awareness and civilization for an individual to contribute for conservation initiatives. Total annual income and income from irrigation were expected to influence positively WTP. Rise of income signifies the increase ability for an individual's WTP. Therefore, the full empirical model was specified as:

$$
\begin{aligned}
& W T P=\beta_{1}(\text { H2OUSEFE })+\beta_{2}(\text { GENDER })+\beta_{3}(\text { MARITALS })+\beta_{4}(\text { EDUCAT })+\beta_{5}(\text { OCCUPAT }) \\
& +\beta_{6}(\text { HHSIZE })+\beta_{7}(\text { PROPTHHE })+\beta_{8}\left(\text { TOTANNU }+\beta_{9}(\text { IRRIINCO })+\beta_{10}(\text { NNHSOUC })+\right. \\
& \beta_{11}(\text { DISTASOU })+\beta_{12}(\text { AMOH } 2 O S O)+\beta_{13}(\text { AMOH } 2 O C O)+\beta_{14}(\text { AMOH } 2 O D R)+\beta_{15}(\text { H } 2 O U S W A S+ \\
& \beta_{16}(H 2 O U S E D W)+\beta_{17}(\text { H2OUSEDT })+\beta_{18}(\text { PRICEH } 2 O)+\beta_{19}(\text { SIZELAND })+\beta_{20}(\text { AMOPAIDI })+ \\
& \beta_{21}(\text { YIELDIPP })+\beta_{22}(\text { YIELDNON })+\beta_{23}(\text { H2OUSERI })+\varepsilon .
\end{aligned}
$$

Where: 
WTP $=$ Willingness to pay for watershed conservation;

H2OUSEFE $=$ Water use fee; GENDER $=$ Gender; MARITALS = Marital status;

EDUCAT $=$ Education level; OCCUPAT $=$ Occupation $;=$ HHSIZE $=$ Household size;

PROPTHHE $=$ Number household members engaged in income generating activities;

TOTANNUA $=$ Total annual income; IRRIINCO = Irrigation income; NHHSOURC $=$ Household water sources $=$ DISTASOU $=$ Distance from the water sources; $\mathrm{AMOH} 2 \mathrm{OSO}=$ Amount of water from other sources; $\mathrm{AMOH} 2 \mathrm{OCO}=$ Water used for cooking; $\mathrm{AMOH} 2 \mathrm{ODR}=$ Water used for drinking; H2OUSWAS = Water used for washing clothes; H2OUSEDW $=$ Water used for washing dishes; H2OUSEDT $=$ Water used for toilets; PRICEH2O = Price for water = SIZELAND = Total land size; AMOPAIDI = Amount paid for irrigation;YIELDIRR = Yield with irrigation; YIELDNON $=$ Yield without irrigation $=$ and H2OUSERI $=$ Water use for irrigation .

\subsubsection{Strengths and weaknesses of CVM approach}

CVM approach is preferred over other valuation methods due to the following because is enormously flexible (i.e. it can be used to estimate the economic value of various ES; it can be used to recover existence (nonusage) values that can't be assessed through market approaches; can produce estimates that are sufficiently reliable to be the starting point for administrative and judicial determinations; it studies allows elicitation of beliefs and opinions that underlie preferences that determine values; has great flexibility that can allow valuation of a wider variety of nonmarket ES than all the indirect valuation techniques; is the most commonly used approach used to estimate the non-use value of the environment (including existence, bequest, and option value) through directly surveying respondents on their WTP; and can be utilized in both, policy analysis and academic research.

Despite the strengths and usefulness of CVM methods in capturing non-marketed ES, there are a number of weaknesses (Carson et al., 2001). They include: the method is 
based on people's opinions as opposed to observing their actual behavior; the validity and accuracy of a CVM study is enhanced if people are familiar with the ES to be valued; is complicated to design a CVM scenario appropriately on ecological studies especially to accurately elicit the values for the ES without information and interviewer bias (es); CVM can provide useful and reliable information, but it needs to be applied carefully; to name just a few.

\section{RESULTS}

\subsection{Socio-economic characteristics of respondents on WTP}

As expected prior to this study, we found that majority of the respondents (79\%) were willing to contribute for watershed conservation (Table III). As indicated in the table below, majority of them preferred to pay between $6(33.6 \%)$ and $12(37.8 \%)$ months. These preferred time scale for payment links well with harvesting seasons where smallholder farmers in PRB have two farming and harvesting seasons.

Table III: Responses on perceptions on WTP for watershed conservation

\begin{tabular}{|c|c|c|c|}
\hline \multicolumn{2}{|l|}{ Variable } & \multirow{2}{*}{$\begin{array}{l}\text { Counts } \\
(n=360)\end{array}$} & \multirow[t]{2}{*}{ Percentages } \\
\hline Contribution & & & \\
\hline \multirow[t]{3}{*}{ conservation } & Willing & 286 & 79 \\
\hline & Not willing & 74 & 21 \\
\hline & & $n=259$ & \\
\hline Time frame for & 12 months & 136 & 37.8 \\
\hline \multirow[t]{3}{*}{ payment } & 6 months & 121 & 33.6 \\
\hline & 1 month & 2 & 0.6 \\
\hline & & $\mathrm{n}=285$ & \\
\hline \multirow[t]{2}{*}{ Certainty about WTP } & 1-5 Very/certain & 258 & 90.5 \\
\hline & 6-10 Very/uncertain & 27 & 9.5 \\
\hline & & $\mathbf{n}=\mathbf{2 7 7}$ & \\
\hline \multirow[t]{3}{*}{ Reasons for WTP } & $\begin{array}{l}\text { Dependency on water for } \\
\text { household and irrigation } \\
\text { uses }\end{array}$ & 134 & 48.4 \\
\hline & $\begin{array}{l}\text { Sustainable water flow } \\
\text { for future generations }\end{array}$ & 130 & 46.9 \\
\hline & $\begin{array}{l}\text { Watershed conservation } \\
\text { for flow of ES }\end{array}$ & 8 & 2.8 \\
\hline
\end{tabular}


Conservation to enhance

WTP for marginal Willingness to wait

Furthermore, we found that majority of smallholder farmers $(90.5 \%)$ were confident of their decision and ability to pay WTP. Reasons for their certainty for WTP include: their dependency on water for household and irrigation uses; sustainable water flow for future generations; watershed conservation for flow of ES; and watershed conservation to enhance ecological integrity. With regards to the marginal effects of conservation programmes, majority of respondents $(78 \%)$ were willing wait for a unit increase water flow as an output of their payment for watershed conservation (Table III).

\subsection{Socio-economic drivers and marginal effects on water users' WTP}

Table IV reveals drivers and their corresponding marginal probabilities for farmer's WTP where six variables indicated statistical significance on WTP at $1 \%(\mathrm{p}<0.001)$ probability level. They includes: marital status (MARITALS), education level (EDUCAT), household size (HHSIZE), total annual income (TOTANNUA), distance from the water sources (DISTASOU) and total land size (SIZELAND).

Table IV: Marginal probabilities for small holder farmer's WTP for watershed services

\begin{tabular}{lcccc}
\hline Variable & $\begin{array}{c}\text { Marginal } \\
\text { probability } \\
(\partial y / \partial x)\end{array}$ & $\begin{array}{c}\text { Standard } \\
\text { error }\end{array}$ & $\mathbf{z}$ & $\begin{array}{c}\mathbf{P}(\mid \mathbf{z} \\
\mid>\mathbf{z})\end{array}$ \\
\hline Water use fee & $-0.325 \mathrm{e}-06^{*}$ & $0.190 \mathrm{e}-06$ & -1.714 & 0.0866 \\
Gender(1=female) & $-0.166 \mathrm{e}-01$ & $0.496 \mathrm{e}-01$ & -0.335 & 0.7380 \\
Marital status (1=married) & $0.135 \mathrm{e}-03^{* * *}$ & $0.038 \mathrm{e}-03$ & 3.501 & 0.0012 \\
Education level & $-0.731 \mathrm{e}-02^{* * *}$ & $0.336 \mathrm{e}-01$ & -2.178 & 0.0263 \\
Occupation & $0.729 \mathrm{e}-01^{*}$ & $0.408 \mathrm{e}-01$ & 1.787 & 0.0739 \\
Household size & $0.151 \mathrm{e}-01^{* * *}$ & $0.074 \mathrm{e}-01$ & 2.036 & 0.0282 \\
Number of hh members engaged & $-0.295 \mathrm{e}-03^{*}$ & $0.161 \mathrm{e}-03$ & -1.831 & 0.0672 \\
in income generating activities & & & & \\
Total annual income & $-0.923 \mathrm{e}-07^{* * *}$ & $0.334 \mathrm{e}-07$ & -2.762 & 0.0058 \\
Irrigation income & $0.450 \mathrm{e}-07^{* *}$ & $0.234 \mathrm{e}-07$ & 1.925 & 0.0505 \\
Household water sources & $-0.128 \mathrm{e}-03^{*}$ & $0.081 \mathrm{e}-03$ & -1.572 & 0.0946
\end{tabular}




\begin{tabular}{lrrrr} 
Distance from the water sources & $0.171 \mathrm{e}-03^{* * *}$ & $0.760 \mathrm{e}-04$ & 2.247 & 0.0247 \\
Amount of water from other & $-0.112 \mathrm{e}-03$ & $0.836 \mathrm{e}-04$ & -1.335 & 0.1819 \\
sources & & & & \\
Water used for cooking & $0.207 \mathrm{e}-02$ & $0.533 \mathrm{e}-02$ & 0.388 & 0.6978 \\
Water used for drinking & $0.114 \mathrm{e}-01$ & $0.294 \mathrm{e}-01$ & 0.386 & 0.6997 \\
Water used for washing clothes & $0.205 \mathrm{e}-01$ & $0.153 \mathrm{e}-01$ & 1.342 & 0.1795 \\
Water used for washing dishes & $-0.357 \mathrm{e}-01$ & $0.299 \mathrm{e}-01$ & -1.193 & 0.2330 \\
Water used for toilets & $0.144 \mathrm{e}-03$ & $0.146 \mathrm{e}-03$ & 0.988 & 0.3234 \\
Price for water & $-0.257 \mathrm{e}-05$ & $0.932 \mathrm{e}-05$ & -0.276 & 0.7826 \\
Total land size (ha) & $-0.622 \mathrm{e}-044^{* *}$ & $0.225 \mathrm{e}-03$ & 2.761 & 0.0059 \\
Amount paid for irrigation & $0.180 \mathrm{e}-06^{*}$ & $0.107 \mathrm{e}-06$ & 1.684 & 0.0847 \\
Yield with irrigation & $0.102 \mathrm{e}-04^{*}$ & $0.581 \mathrm{e}-05$ & 1.760 & 0.0685 \\
Yield without irrigation & $-0.152 \mathrm{e}-05$ & $0.919 \mathrm{e}-05$ & -0.166 & 0.8683 \\
Water use for irrigation & $-0.218 \mathrm{e}-03^{*}$ & $0.143 \mathrm{e}-03$ & -1.522 & 0.0984 \\
\hline
\end{tabular}

Number of observations $(\mathrm{N})=360$

Log Likelihood $=-219.63367$

LRChi2=3.41964

Prob-Chi2 $=0.8238571 \mathrm{e}-04$

Note: ${ }^{* * *},{ }^{* *},{ }^{*}$ indicates significance at $1 \%, 5 \%$, and $10 \%$ levels of significance respectively

As expected in the hypothetical direction of the respondent's opinion (Table II), marital status (MARITALS), household size (HHSIZE), and distance from the water sources (DISTASOU) influenced positively respondent's WTP for watershed conservation. The positive sign for marital status (MARITALS) implies that the WTP for watershed conservation increases as one get married. It is hypothesized that married couples are likely to have higher WTP because of the increase in water use in their household and also the expectation to have other members in the family (i.e. children). Similarly, the positive sign for household size (HHSIZE) means that as the number of household members increases, the probability of WTP for that household increases as well. Moreover, the positive sign for the distance from the water sources (DISTASOU) implies that, as the distance from the water sources increase, it increases the probability of people's WTP for the construction of nearby water sources. The positive direction of these variables concurs with the theoretical expectation hypothesized in Table II.

On the other hand, the education level (EDUCAT) and total annual income (TOTANNUA) had negative signs thereby reducing respondent's probability WTP for 
watershed conservation. These results are contrary to the hypothesized sign in Table II and the expectation of the theoretical model. The negative sign of the education level (EDUCAT) is implies that education level reduces respondent's probability for WTP for watershed conservation. Also the negative sign of the total annual income (TOTANNUA) implies that total annual income (TOTANNUA) reduces respondent's probability for WTP for watershed conservation. These findings are contrary to the hypothesized opinion direction in Table II, the theoretical model is contrary to the study by Amponin et al. (2007), and Farolfi et al. (2007), who found that income increase influenced people's WTP for watershed protection for domestic water supply in (Tuguegarao City) Philippines and Swaziland respectively.

\subsection{Determinants of the amount for WTP for the watershed conservation}

Table $\mathrm{V}$ reveals factors that determine the amount that smallholder farmers are WTP. Factors that determined significantly this amount includes: education level, occupation, household size, irrigation income, water used for washing dishes, total land size (ha), amount paid for irrigation and crop yield with irrigation.

\section{Table V: Maximum amount small holder farmer's WTP}

\begin{tabular}{lrrrr}
\hline Variable & Coefficient & \multicolumn{1}{c}{$\begin{array}{c}\text { Standard } \\
\text { error }\end{array}$} & b/St.Er & P[|Z|>z] \\
\hline Willingness to pay & $22261.83038^{* * *}$ & 10520.5486 & 2.116 & 0.0183 \\
WTP certainty & $3.670318282^{* *}$ & 1.9170822 & 1.915 & 0.0556 \\
Water use fee & $-3.05 \mathrm{E}-04$ & $5.16 \mathrm{E}-03$ & -0.059 & 0.9528 \\
Gender (1=female) & $-6527.65341^{* * *}$ & 1465.0761 & -4.456 & 0 \\
Marital status & $17.379702^{* * *}$ & 4.9702078 & 3.497 & 0.0005 \\
Education level & $4511.653016^{* * *}$ & 1594.595 & 2.829 & 0.0047 \\
Occupation & $172.3448633^{* * *}$ & 81.62695 & 2.111 & 0.0094 \\
Household size & $-121.119996^{*}$ & 67.44146 & -1.795 & 0.0693 \\
Number hh members engaged in & & & & \\
income generating activities & $1.442747865^{* * *}$ & 0.6407413 & 2.252 & 0.0217 \\
Total annual income & $1.36 \mathrm{E}-04^{* * *}$ & $6.56 \mathrm{E}-05$ & 2.079 & 0.0098 \\
Irrigation income & $1.93 \mathrm{E}-04$ & $6.66 \mathrm{E}-04$ & 0.29 & 0.7719 \\
Household water sources & $-9.11648574^{* *}$ & 4.7719495 & -1.91 & 0.0561 \\
Distance from the water sources & $8.84 \mathrm{E}-02$ & 2.1981903 & 0.04 & 0.9679
\end{tabular}




\begin{tabular}{lrrrr} 
Amount of water from other sources & $-6.32423857^{* * *}$ & 2.6047383 & -2.428 & 0.0152 \\
Water used for cooking & $1.93 \mathrm{E}-04$ & $6.66 \mathrm{E}-04$ & 0.29 & 0.7719 \\
Water used for drinking & 419.3810105 & 791.71684 & 0.53 & 0.5963 \\
Water used for washing clothes & $870.0716956^{*}$ & 480.05976 & 1.812 & 0.0699 \\
Water used for washing dishes & -12.2853168 & 10.825056 & -1.135 & 0.2564 \\
Water used for toilets & 5.477136869 & 5.7441356 & 0.954 & 0.3403 \\
Price for water & $-1.01 \mathrm{E}-02$ & $2.44 \mathrm{E}-01$ & -0.041 & 0.967 \\
Total land size (ha) & $1.557890715^{*}$ & 0.95378501 & 1.633 & 0.0743 \\
Amount paid for irrigation & $-3.78 \mathrm{E}-02^{* * *}$ & $1.48 \mathrm{E}-02$ & -2.557 & 0.0056 \\
Yield with irrigation & 0.617585859 & $2.71 \mathrm{E}-01$ & 2.275 & 0.0187 \\
Yield without irrigation & $-9.54 \mathrm{E}-01^{*}$ & $6.17 \mathrm{E}-01$ & -1.545 & 0.1223 \\
Water use for irrigation & -2.89293972 & 5.527303 & -0.523 & 0.6007 \\
\hline
\end{tabular}

Number of observations $(\mathrm{N})=360$

Log-L= -1290.48

Threshold values for the Model: Lower $=.000$ Upper $=+\infty$

LM test [df] for tobit $=94.576$

ANOVA based fit measure $=13.636318$

DECOMP based fit measure $=0.473343$

Note: ${ }^{* * *},{ }^{* *},{ }^{*}$ indicates significance at $1 \%, 5 \%$, and $10 \%$ levels of significance respectively

The positive sign for education level, water used for washing dishes, total land size and crop yield with irrigation implies that these factors influenced positively on the probability of the amounts that respondents are WTP for watershed conservation. On the other hand negative sign for occupation, household size, irrigation income and amount paid for irrigation implies that influence negatively on the probability of the maximum amount that respondents are WTP for watershed conservation.

However, overall Table V the WTP had positive influence on WTP and statistically in indicated a significant influence at $1 \%(\mathrm{p}<0.000)$ probability level. In addition, the goodness fit of the linear model explained 0.62 (i.e. 62\%) variation of the variables used in the computation. The rest, i.e. 38\% may have been affected by external factors (i.e. some errors) during data acquisition, handling, processing and analysis. 


\section{DISCUSSIONS}

\subsection{Socio-economic characteristics of respondents on WTP}

Overall, smallholder farmers have high level awareness on watershed conservation along the PRB. This has been testified by their willingness to contribute (76\%) for watershed conservation (Table III). Respondent's willingness to contribute for watershed conservation may be due to the high demand of watershed services (water) they need from therein. Due to climate change and climate variation (Lalika et al., 2015b), smallholder farmers depend much on irrigated agriculture, and this justifies their awareness and willingness to contribute for watershed conservation.

Smallholder farmers along the PRB seem to be embracing the concept of sustainable development. The fact that they are WTP for watershed conservation in order to enhance sustainable water flow and for increased flow of ES and ecological integrity is in itself a testimony of their awareness on watershed conservation (Calderon et al., 2005). Normally conservation schemes take a considerable long time in order to yield lasting results. Respondents seem also to know this that's why they are willing to wait for the output of this conservation initiative.

\subsection{Socio-economic drivers influencing water user's WTP}

The level and spirit of respondents to be WTP for watershed conservation (Table III and $\mathrm{V})$ is an encouraging indicator for the sustainability of watershed ecosystem. Majority of smallholder farmers in the PRB are willing to contribute for financing watershed conservation in order to ensure the sustainability of water flow. However, the direction of the hypothesized model in Table II differs with the influence of some of the variables displayed in Table IV.

Normally, education determines the level of awareness and willingness to participate and contribute for conservation initiatives. It is perceived that an educated person is civilized and can make wise decisions driven by accumulated knowledge through 
education (Mohamed et al., 2012). On the contrary, findings of this study indicated that education had negative influence on respondent's WTP (Table IV). The negative sign means that the more an individual is educated the less that person is WTP for watershed conservation. In developing countries like Tanzania, majority of people with better education reside in urban areas. It is likely that they have more / alternative income sources which enable them to access water from other sources (e.g. bottled, tap water and from private boreholes). For this reason, they may have little interest on watershed conservation. This observation differs completely with the theoretical assumption on education (Table II) and the observation by Samdin et al. (2010), who asserted that "in normality, decision making made by educated communities are more fundamental due to knowledge advantages they owned. Therefore, their decisions towards WTP are influenced by their developed knowledge rather than emotion driven decisions".

As indicated in Table II, the variable income indicated positive and statistical influence on WTP. Normally, income level is a crucial determinant for one's ability to contribute or participate in conservation activities. The positive sign of income level implies that as the income raises the household's WTP for watershed conservation. In other words the household's WTP increases with increase in income level (Day and Mourato, 1998; Fujita et al., 2005; Park and Turker, 2006; Ghorbani and Hamraz, 2009; Sathya and Sekar, 2012). Generally, communities with enough income can be able to finance human basic needs (i.e. food, clothing and shelter) and spare surplus for investing in conservation activities. This observation in Table II concur with the findings by Farolfi et al. (2007), who found that income level had a positive and statistically significant impact on WTP for domestic water supply in Swaziland.

The positive sign and statistical significance for the distance from the water source indicated in Table IV confirms the assumption put forward earlier in Table II. Usually it is expected that the longer the distance a household is located from water sources, the higher the WTP would be for that particular household for financing the establishment 
of a nearby water sources (Marrett, 2002). People who walk longer distances looking for water are likely to be WTP for construction of a new water source that would reduce their walking distances. Therefore, local communities are WTP for watershed conservation in the sense that their financial contributions are likely to restore degraded watersheds, enhance water flow along rivers and finally enable installation of more standing tap water.

\subsection{Factors influencing the amount smallholder farmers' WTP}

As indicated in Table V, education level, water used for washing dishes, total land size and crop yield with irrigation influence positively the maximum amount that smallholder farmer's are WTP. The positive sign for education level implies that the maximum amount that a respondent is WTP for watershed conservation is determined by the number of years spend in education. In other words, the WTP for watershed conservation increases with the increase level of education. This implies that many years in education create awareness on environmental conservation.

The positive sign for the total land size determines the amount for maximum WTP. Large land size increases the possibility of getting many bags of crop harvest contrary to the one with small land size (given that factor such as mechanization and capital investments are held constant). Therefore, the positive sign for this variable means that as the size of land for agriculture increases, the maximum amount for WTP increases as well because smallholder farmers are motivation by the quantity of crop harvest. This interpretation applies also to other factors with positive sign.

On the other hand occupation, household size, irrigation income, and amount paid (fee) for irrigation influenced negatively the maximum amount for WTP. The negative sign for occupation implies that the WTP for watershed conservation for a particular household is reduced with occupation type. Some occupations have higher payments/returns with surplus income for contributing to conservation activities. 
Therefore, occupation type determines respondent's WTP and the amount to pay. In the PRB the income level is normally determined by type of employment or occupation. A person who is employed in a lowly paid position is likely to be less WTP for watershed conservation because the low paid income is likely to be allocated to expenditures on subsistence needs. Therefore, the negative sign for occupation implies that poor paid jobs are likely to discourage an individual to contribute higher amount for conservation as opposed to employee who are holding positions with higher salaries.

The same case applies to the household size, irrigation income and amount paid for irrigation. The negative sign for household size implies that increase of household members reduces the WTP of that household for watershed conservation. Therefore, large household sizes increases expenditure on water thereby, reducing its maximum amount for WTP for watershed conservation. The same case applies to the amount paid for irrigation. The negative sign for irrigation income means that increase of water use fees for irrigation water, reduces the maximum amount that smallholder farmer' are WTP for watershed conservation. In other words, the higher the cost of irrigation water, the less is the amount that irrigators are WTP for watershed conservation.

\section{CONCLUSIONS}

The study reveals local community awareness and their enthusiastic for contributing their income for financing watershed conservation and governance for sustainable water flow (Lalika et al., 2014; 2015a). Furthermore, the study reveals the potential for CVM as a policy tool for soliciting conservation funds from water users. It testifies how water use fees could be a potential and reliable revenue source for financing nature conservation programmes instead of relying on donor funding. Apart from uncovering the possibilities of accumulating funds from local sources for conservation, this study reveals the potential for generating funds from downstream water users to support upstream communities who would be willing to implement watershed conservation practices (Bakaki and Bernauer, 2016; Nyongesa et al., 2016). 
Although CVM studies are normally hypothetical in nature, i.e. they depend on people's opinions (Carson et al., 2001) they are quite useful and have been extensively used in different parts of the world (Elizabeth et al., 2016). Specific to this study, CVM results shows how socio-economic factors can influence people's WTP and the amount that they are WTP for watershed conservation (Castro et al., 2016). Results from this study would be a basis for resource valuation in other areas in Tanzania facing similar problems like in the PRB.

Furthermore, the study has indicated that given the current water scarcity along the PRB, small holder farmers are WTP for increased water flow. As explained above, CVM studies are theoretical in nature and new paradigm for watershed conservation along the PRB in Tanzania. Although, success stories of WTP for watershed conservation have not been documented in great detail across the globe, some studies (Day and Mourato, 1998; Whittington, 1998; 2002; Carson et al., 2001; Zhongmin et al., 2003; Amponin et al., 2007; Awad and Holländer, 2010) supports the potential for CVM/WTP studies as tool for conservation and policy planning. Although WTP may not be a correct and recommended paradigm in Tanzania, its potential in capturing nonmarket values remains a key asset for related research in future.

\section{Acknowledgements}

The financial support for this work came from the government of Belgium (scholarship grant number 09TAN/5917) through the Belgium Technical Cooperation (BTC). Authors are grateful to research assistants MS. Mariam Ramadhani and Ms. Mariam Muya, for their tireless efforts during socio-economic surveys in the study villages. We convey out gratitude thanks to anonymous reviewers for the comments during the final stages of the preparation of this paper. Their constructive suggestions and inputs remains a permanent assert for reporting similar scientific works in future. 


\section{Conflicts of interest}

There is no conflict of interest in this paper. This work is a small portion of a $\mathrm{PhD}$ research financed by the government of Belgium through the Belgium Technical Cooperation (BTC).

\section{REFERENCES}

Amponin, J. A., Bennagen, E., Hess, S., and Cruz, D.J., 2007. Willingness to pay for watershed protection by domestic water users in Tuguegarao City, Philippines. Poverty Reduction and Environmental Management (PREM) Working Paper 07/06 ASEAN Center for Biodiversity.[http://www.premonline.org/archive/5/doc/PREM\%20WP\%2007-06] Visited 28 March 2013.

Awad, I. and Holländer, R., 2010. Applying Contingent Valuation Method to

Measure the Total Economic Value of Domestic Water Services: A Case Study in Ramallah Governorate, Palestine. European Journal of Economics, Finance and Administrative Sciences, 10: 2010.

Bakaki, Z and Bernauer, T. 2016. Measuring and explaining the willingness to pay for forest conservation: evidence from a survey experiment in Brazil. Environ. Res. Lett., 11, 114001. doi:10.1088/1748-9326/11/11/114001

Bateman, I., Cooper, P., Georgiou, S.,Navrud, S., Poe, G., Ready, R., Riera, P., Ryan,M., Vossler, C., 2005. Economic valuation of policies for managing acidity in remote mountain lakes: examining validity through scope sensitivity testing. Aquatic Sciences - Research Across Boundaries 67, 274-291.Bateman, I.J., Carson, R.T., Day B.,

Hanemann, M., Hanley, N., Hett, T., Jones-Lee, M., Loomes, G., Mourato, S., Ozdemigorlu, E., Pearce, D.W., Sugden, R. and Swanson, J., 2002. Economic Valuationwith Stated Preference Techniques: A Manual. Edward Elgar Publishing, Inc. USA.

Calder, I.R., 2007. Forests and water-ensuring forest benefits outweigh water costs. Forest Ecology and Management 251, 110-120

Calderon, M. C., Camacho, L., Carandang, M., Dizon, J., Rebugio, L., and Tolentino, N., 2005. A water user fee for households in Metro Manila, Philippines. Research Report for the Economy and Environment Program. http://web.idrc.ca/uploads/userS/11201068811MargeRR2[visited 19 February, 2013]

Champ, P.A., Boyle, K.J., and Brown, T.C., 2003. A Primer on Nonmarket Valuation. The economics of non-market goods and resources. Kluwer Academic Publishers, Dordrecht.

Carson, R. T., Flores, N. E., and Meade, N. F., 2001. Contingent valuation: Controversies and evidence. Environmental and Resource Economics 19, 173-210. 
Castro, A., Vaughn, C., García-Llorente, M., Julian, J., and Atkinson, C. 2016. "Willingness to Pay for Ecosystem Services among Stakeholder Groups in a South-Central U.S. Watershed with Regional Conflict." Water Resour. Plann. Manage., 10.1061/(ASCE)WR.1943-5452.0000671, 05016006

Costanza, R., d'Arge, R., de Groot, R.S., Farber, S., Grasso, M., Hannon, B., Limburg, K., Naeem, S., O'Neill, R.V., Paruelo, J., Raskin, R.G., Sutton, P., van den Belt, M., 1997. The value of the world's ecosystem services and natural capital.Nature 387, 253-260.

Day, B. and Mourato, S., 1998. Willingness to Paya for W ater Quality in Chinesse

Rivers: Working Paper No: WM 98-02. Centre for Social and Economic Research on the Global Environament, London, UK.

De Groot, R.S., Wilson M.A. and Boumans, R.M.J., 2002. The dynamics and value of ecosystem services: Integrating economic and ecological perspectives. A typology for the classification, description and valuation of ecosystem functions, goods and services. Ecological Economics 41, 393 - 40827.

Dobbs, T.L., and Pretty, J. 2008. Case study of agri-environmental payments: the United Kingdom. Ecological Economics vol. 65:766-776 (this issue).

Elizabeth T. Carig, E.T., Joel G. Carig, J.G. and Vallesteros., A.P. 2016. Assessment of Willingness to Pay as a Source of Financing for the Sustainable Development of Barobbob Watershed in Nueva Vizcaya, Philippines. Geoscience and Environment Protection, 4: 38-45

Farolfi, S. Mabugu,R.E. and Ntshingila, S.N., 2007. Domestic Water Use and Values in Swaziland: A Contingent Valuation Analysis.Agrekon,Vol 46, No 1

Fujita, Y., Fujii, A., Furukawa, S. and Ogawa T., 2005. Estimation for Willingness-toPay for Water and Sanitation through a Contingent Valuation Method (CVM): A case study in Iquitos City, The Republic of Peru. Japan Bank for International Cooperation.Pg 59 - 87. http://www.jbic.og.jp/en/research/report.jbicreview/pdf/report10_2pdf

Haab T. and K. McConnell., 2003. Valuing Environmental and Natural Resources. The Econometrics of Non-Market Valuation (Paperback edition), Edward Elgar, Northampton, MA (2003).

Herrera P., G. Huylenbroeck, and R. Espinel. 2004, An Application of the Contingent Valuation Method to Assess the Efficiency of the Institutional Structure of Irrigation Property Rights: The Case of the Peninsula of Santa Elena, Ecuador, Journal of Water Resources Development, 20 (4): 537-551

Ghorbani, M. and Hamraz, S., 2009. A survey on factors affecting on consumer's Willingness to pay for organic products in Iran (A case study).Trends in Agriculture Economics 2, 10 - 16

Green, D., Jakowitz, K.E., Kahneman, D., and McFadden, D., 1995. 'Referendum contingent valuation, anchoring, and willingness to pay for public goods'. A paper presented at the August 1995 World Congress of the Econometric Society, Tokyo. 
Green, W.H., 2003. Econometric analysis: International Edition. $5^{\text {th }}$ edition.Price Hall. New York.

Griffiths, W.F., Hill, R.C., and Judge, G.G., 1993. Leaning and practicing Econometrics.John Willey and Sons, Inc. New York. $886 \mathrm{pp}$.

Hanemann, W.M., Kristrom, B., Li, C.Z., 1996. Nonmarket valuation under preference uncertainty: econometric models and estimation.

Hanley, N., Kriström, B., Shogren, J.F., 2009. Coherent arbitrariness: on value uncertainty for environmental goods. Land Economics 85, 41-50.

Heal, G. M., E.B. Barbier, K.J. Boyle, A.P. Covich, S.P. Gloss, and Hershner, C.H. 2005. Valuing ecosystem services: toward better environmental decision-making. National Academy Press. Washington, D.C.

IUCN and PBWO., 2008. Scenario Report: The analysis of water allocation scenarios for the Pangani River Basin. Moshi, Tanzania: The World Conservation Union (IUCN) and Pangani Basin Water Office (PBWO).

IUCN., 2007. Pangani River System.State of the Basin Report - 2007 Tanzania.

Submitted to Pangani Basin Water Office and IUCN Eastern Africa Regional Office. 51pp

IUCN., 2003. Pangani Basin: A situation analysis. IUCN Eastern Africa Programme, Nairobi. 104pp.

Khanal, R. and Paudel, D., 2012. Payment for Ecosystem Services (PES) Schemes for Conserving Sardu Watershed Nepal: Existing Practices and Future Prospects.Technical Working Paper. 12p.

Kulindwa, A.A., 2005. Payments for Environmental Hydrological Services.Policy Briefs Water Resources Management in Pangani River Basin Tanzania. Economic Research Bureau, University of Dar es Salaam. Issue No 2 October 2005.

Lalika, M.C.S., Meire., P. and Ngaga, Y. M. 2015a. Exploring watershed conservation and water governance along the Pangani River Basin, Tanzania. Land Use Policy, 48: $351-361$

Lalika, M.C.S., Meire., P. Ngaga, Y. M. and Chang'a, L. 2015b. Watershed dynamics and climate change and climate variability along Pangani River Basin, Tanzania. Ecohydrology and Hydrobiology, 15 (1): 26 - 38

Lalika, M.C.S., Meire., P. and Ngaga, Y. M. 2015c. Paying to Conserve Watershed Services in Pangani River Basin Tanzania. In: Hipel, K, W, Fang, L., Cullmann, J. and Bristow, M. (eds.). "Conflict Resolution in Water Resources and Environmental Management". Springer (Heidelberg). Germany. ISBN 978-3-319-14214-2

Lalika, M.C.S., Meire., P. Ngaga, Y. M. and Ngowi, S. E. 2014. Analyzing Ecosystem Services at Watershed Scale: Implications for Conservation in Upper Kikuletwa 
Sub-Catchment, Tanzania. In: Donke, M. (ed.), “Welcome to Africa: Climate Change Adaptation in Eastern Africa." 4 - 12 March, 2013, Khartoum / El-Obeid, Sudan. Edited and published conference proceedings: 204 - 223. ISBN 978-3-942934-03-9.

Lalika, M.C.S., de Deckere, E. and Ngaga, Y.M., 2011. Payment for Water Services as Basis for Natural Resource Management: Experience from Pangani Basin Tanzania. In: Anderson K., Okeyo-Owur, J.B. and Hezron, M. (eds), Towards Implementation of Payment for Environmental Services (PES).BOD Publishers, London. Pp 176-195.

Lambrechts, C., Woodley, B., Hemp, A., Hemp, C. and Nyiti, P., 2002. Aerial survey of the threats to Mount Kilimanjaro forests. United Nation Development Programme (UNDP). Dar es Salaam, Tanzania. 48pp.

Liquete, C., Maes, J., La Notte, A. and Bidoglio, G., 2011. Securing water as a resource for society: An ecosystem service perspective. Ecohydrology and hydrobiology 11 (34), 247 - 259

Locatelli, B.and Vignola, R., 2009.Managing watershed services of tropical forests and plantations: Can meta-analyses help? Forest Ecology and Management 258, 1864-1870

Long, S.J., 1997.Regression Models for Categorical and Limited Dependent Variables: Advanced Quantitative Techniques in the Social Sciences Series 7. SAGE Publications, London, UK.

Loomis J., P. Kent, L. Strange, K. Fausch, and A. Covich, 2000. Measuring the Total Economic Value of Restoring Ecosystem Services in an Impaired River Basin: Results from a Contingent Valuation Survey. Ecological Economics, 33: 103-117

Maddala, G.S., 1987. Limited Dependent and Qualitative Variables in Econometrics. Econometrics Society Monographs No.3, Cambridge University Press, New York, NY.

Marrett, S., 2002.Deconstructing Household's Willingness-to-pay for Water in LowIncome Countries. Water Policy 4, 157-172

Mbeyale, G, E., 2009. The Impact Institutional Changes on the Management of Common Pool Resources in Pangani River Basin, Same District Kilimanjaro Tanzania. Unpublished PhD Thesis Submitted in Fulfilment for the Degree of Philosophy of the University of Dar es Salaam. 334pp.

Mbonile, M.J., 2005. "Migration and intensification of water conflicts in the Pangani basin, Tanzania." Habitat International 29, 41-67.

MEA., 2005. Ecosystems and Human Well-Being: Synthesis. Millennium Ecosystem Assessment. Island Press, Washington, DC.

Mohamed, N., Shamsudin, M.N., Ghani, A.N.A., Radam, A., Khaffashi, S., Rahim, N.N.R.N.A., Hassin, N.H.B., 2012.Wilingness to Pay for Watershed Conservation at Hulu Lengat, Selanger.Applies Sciences 12(17), 1859 - 1864.

Msuya, T. S., 2010. Developing Integrated Institutional Framework for Sustainable Watershed Management in Pangani River Basin, Tanzania.Thesis for Award of PhD Degree of Sokoine University of Agriculture, Morogoro, Tanzania. 
Mulungu, D.M.M., 1997. Application of linear models for inflow forecasting to NyumbayaMungu Reservoir in Pangani River basin Tanzania. . Unpublished Master's thesis, Department of Water Resources Engineering, University of Dares Salaam, Tanzania

Mwamila, T.B., Kimwaga, R.J. and Mtalo, F.W., 2008. Eco-hydrology of the Pangani River downstream of NyumbayaMungu reservoir, Tanzania.Physics and Chemistry of the Earth 33, 8-13.

Ndomba, P.M., Mtalo, F.W. and Killingtveit, A. 2008. A guided SWAT model application on sediment yield modeling in Pangani River Basin: Lesson Learnt.Journal of Urban and Environmental Engineering.2, 53-62

Newmark, W.D., 1998. Forest area, fragmentation, and loss in the Eastern Arc Mountains: implications for the conservation of biological diversity. Journal of East AfricanNatural History 87, 1 - 8 .

Nyongesa J. M., Bett, H. K., Lagat, J. K. and Ayuya O. I., 2016. Estimating farmers' stated willingness to accept pay for ecosystem services: case of Lake Naivasha watershed Payment for Ecosystem Services scheme-Kenya. Ecological Processes, 5:15 DOI: 10.1186/s13717-016-0059-z

Okurut, T.O., 2011. Policy and Institutional Framework for Transboundary Payment for Environmental Services. In: Anderson K., Okeyo-Owur, J.B. and Hezron, M. (eds), Towards Implementation of Payment for Environmental Services (PES). BOD Publishers, London. Pp 2 - 14

Ostrom, E., 1990. Governing the Commons. The Evolution of Institutions for Collective Action. Cambridge: Cambridge University Press.

Ostrom, E., Schroeder, L., and Wynne, S., 1993. Institutional Incentives and Sustainable Development.Westview Press, Boulder, Colorado, 264 pp.

Pagiola, S., 2008. Payments for environmental services in Costa Rica. Ecological Economics 65 (4), 712-724.

Pagiola, S., A. Arcenas, and Platais, G., 2005. "Can payments for environmental services help reduce poverty? An exploration of the issues and evidence to date from Latin America."World Development 33 (2), 237-253.

Pagiola, S., Bishop, J. and Landell-Mills, N., 2004a. Market-based Mechanisms for Forest Conservation and Development. In: Pagiola, S., Bishop, J. and Landell-Mills, N., (eds), Selling Forest Environmental Services: Market-based Mechanisms for Conservation and Development. Earthscan Publication Ltd. London, UK. 299pp.

Pagiola, S., Bishop, J. and Landell-Mills, N., (eds), 2004b. Selling Forest Environmental Services: Market-based Mechanisms for Conservation and Development. Earthscan Publication Ltd. 299pp.

Pagiola, S., 2004. Paying for Watershed Services in Central America.In: Pagiola, S., 
Bishop, J. and Landell-Mills, N. (eds.) Selling Forest Environmental Services: Marketbased Mechanisms for Conservation and Development. Earthscan Publication Ltd. London, UK. pp. 37-61

Park, M. and Turker, M.N., 2006. Estimation of recreational use value of forest by Using individual travel cost and contingent valuation methods (Kayabani Forest Recreational Site Sample). Applied Science 6, 1-5.

Pattanayak, S.K. and Randall A. Kramer, R.A., 2001. Pricing ecological services: Willingness to pay for drought mitigation from watershed protection in eastern Indonesia. Water Reources Research, 37 (3) : 771-778.

Porras, I., Grieg-Gran, M. and Neves, N., 2008. All that glitters: A review of payments for watershed services in developing countries. Natural Resource Issues No. 11. International Institute for Environment and Development. London, UK.

Pindyck, R., Rubinfeld, D., 2005. Microeconomics (6th edn). Pearson Prentice Hall, Upper Saddle River, NJ. Poe, G.L., Clark, J.E., Rondeau,

Rosett, R.N., and Nelson, F.D. 1975. Estimation of the two-limit probit regression model. Econometrica 43:141-146.

Samdin, Z., Abdul-Aziz, A., Radam, A. and Yakob, MR., 2010. Factors influencing the willingness to pay for entrance permit: The evidence from Taman Negara National Park. Institute of Tropical Forestry and Forestry Products (INTROP).Sustainable Development.Volume 3.

Sanga, G.J. Moshi, A. B. and Hella, J. P., 2013. Small Scale Farmers' Adaptation to Climate Change Effects in Pangani River Basin and Pemba: Challenges and Opportunities. International Journal of Modern Social Sciences 2(3), 169-194

Sathya, T. and Sekar, 2012. Mangrove ecosystems and their multifuctionalities: An analysis of the provision of economic and environmental livelihoods to the fishermen communities in the South East Cost of India. Trends in Agriculture Economics 3, 32 - 47

Savenije, H. H.G., 2002. Why water is not an ordinary economic good, or why the girl is special. Physics and Chemistry of the Earth 27, 741-744

Shaghude, Y.W., 2006. Review of water resource exploitation and land use pressure in Pangani River Basin, Tanzania. Western Indian Ocean Marine Science Association Journal 5(2), 195-207.

Sotthewes, W., 2008. Forcing on the salinity distribution in Pangani estuary, Tanzania. MSc Thesis submitted in partial fulfillment of Masters of Science at Delft University of Technology, The Netherlands, $82 \mathrm{pp}$.

Stanton, T., Echavarria, M., Hamilton, K. and Ott, C., 2010. State of Watershed Payments: An Emerging Marketplace. Ecosystem Marketplace. http://www.foresttrends. org/documents/files/doc_2438.pdf [accessed March, 2013]

Tietenburg, T., 2002. Environment and Natural Resource Economics (Fifth Edition).Addison-Wesely. UK, pp 630

Turpie, J., Morais, C. and Blignaut, J.N., 2008. The working for water programme: 
Evolution of payment for ecosystem services mechanisms that addresses both poverty and ecosystem services delivery in South Africa. Ecological economics 65, $788-798$.

Turpie, J.; Ngaga, Y. M. and Karanja, F., 2005. Catchment Ecosystems and Downstream Water: The Value of Water Resources in the Pangani Basin, Tanzania, Lao PDR.IUCN Water, Nature and Economics Technical Paper No. 7, IUCN the World Conservation Union, Ecosystems and Livelihoods Group Asia 108pp. http: //www.waterandnature.org. (site visited on June 20, 2013).

Valimba, P. 2005. Rainfall variability in southern Africa, its influences on stream flow variations and its relationships with climatic variations.Unpublished $\mathrm{PhD}$ Thesis, Rhodes University.

Valimba, P., 2007. Spatial variation of hydrological floods during the short rains in Northeast Tanzania, Proc. International Conference on Climate and Water, Helsinki (Finland). 2007. 3-6 September.

Voltaire L., Pirrone, C. and Bailly D., 2013. Dealing with preference uncertainty in contingent willingness to pay for a nature protection program: A new approach. Ecological Economics, 88: 76-85

Whittington, D., 2002. Improving the Performance of Contingent Valuation Studies in Developing Countries. Environmental and Resource Economics 22, 323 - 367

Whittington, D., 1998. Administering contingent valuation surveys in developing countries. World development 26 (1), 21-30

Wooldridge, J.M. 2003. Introductory Econometrics: A Modern Approach. South Western Division of Thomson, USA. 863pp.

Zhongmin X., C. Guodong, Z. Zhinqiang, S. Zhiyong, and J. Loomis. 2003. Applying Contingent Valuation in China to Measure the Total Economic Value of Restoring Ecosystem Services in Ejina Region, Ecological Economics, 44: 345-358. 